\title{
EFFECT OF DEEP PLACEMENT OF NITROGEN FERTILIZERS ON RICE YIELD AND N USE EFFICIENCY UNDER WATER REGIMES
}

\author{
S. Das, M. R. Islam*, M. Sultana, H. Afroz and M. A. Hashem \\ Department of Soil Science, Bangladesh Agricultural University, Mymensingh-2202, Bangladesh
}

\begin{abstract}
The experiments were conducted at the Soil Science Field Laboratory of Bangladesh Agricultural University, Mymensingh during boro season of 2013 to evaluate the effect of deep placement of nitrogen $(N)$ fertilizers on rice yield and $\mathrm{N}$ use efficiency under two different water regimes [continuous flooding (CF) and alternate wetting and drying (AWD)]. After deep placement of USG and NPK briquettes and each split application of $\mathrm{PU}$, the water samples were collected for five consecutive days and analyzed for ammonium-Nitrogen $\left(\mathrm{NH}_{4}-\mathrm{N}\right)$ concentration. In both water regimes the floodwater $\mathrm{NH}_{4}-\mathrm{N}$ concentration gave highest value at the second day of PU application followed by gradual decrease with time and in continuous flooding condition the release of $\mathrm{NH}_{4}-\mathrm{N}$ was higher compared to AWD condition. Deep placement of $\mathrm{N}$ fertilizers also increased grain yield under AWD compared to CF condition and the maximum value was obtained in treatment $T_{5}$ [USG 78

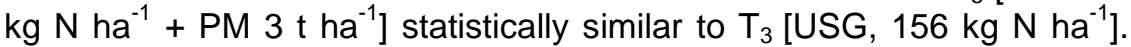
Due to application USG and NPK briquettes, the N uptake and N use efficiency also gave higher values in AWD compared to CF condition. The results revealed that the deep placement of USG with poultry manure performed better in terms yield, $\mathrm{N}$ uptake and $\mathrm{N}$ use efficiency by BRRI dhan29 under AWD condition. So, the deep placement of USG under AWD condition could be recommended for higher production of boro rice.
\end{abstract}

Keywords: Deep placement of $\mathrm{N}$, flood water ammonium, rice yield, nitrogen use efficiency, continuous flooding (CF), alternate wetting and drying (AWD)

\section{INTRODUCTION}

In Bangladesh, rice is grown under diverse irrigated, rainfed and deep water conditions in the three distinct seasons, namely Aus, Aman and Boro. Out of total

*Corresponding author email: mrislam69@yahoo.com 
rice production in this country about $43 \%$ comes from boro and the rest comes from Aman and Aus crops (BBS, 2011). For cultivation of rice, farmers of Bangladesh solely depend on urea fertilizer and $50 \%$ of the total demand is fulfilled by import which costs a huge amount of foreign currency (BBS, 2012). On the other hand, excessive $\mathrm{N}$ fertilization is one of the major concerns in sustainable agriculture for its decreased $\mathrm{N}$-utilization efficiency by crops and increased $\mathrm{N}$ release to the environment, resulting atmosphere and water pollution (Zhu et al., 1997). The volatilization loss of prilled urea $(\mathrm{PU})$ is very high and farmers lose a huge amount of money for $\mathrm{N}$ fertilizer. Therefore, the deep placement of urea super granule (USG) might be a good option to minimize the production cost as well as to increase crop yield. Ammonia volatilization losses in the flooded soils range from negligible to almost $60 \%$ of the applied N (Xing and Zhu, 2000). Deep placement of N fertilizers into the anaerobic soil zone is an effective method to reduce volatilization loss (Mikkelsen et al., 1978).

Again, water shortage during the boro season in Bangladesh is a growing problem due to climatic change and upstream water regulation of the major rivers in Bangladesh. One major recent advance in rice water management is termed Alternate Wetting and Drying (AWD) which combines the beneficial aspects of both aerobic and anaerobic cultivation. For AWD practices, the fields are managed as irrigated lowland rice but the top soil layer is allowed to dry out to some degree before irrigation is applied again (Belder et al., 2004).

The number of days under non-flooded soil conditions can vary depending on plant development stages and availability of water. The AWD irrigation causing alternating oxic and anoxic conditions in top soil may lead to increased $\mathrm{N}$ losses from coupled nitrification-denitrification (Nicolaisen et al., 2004; Liu et al., 2010). Denitrification loss could be enhanced under AWD irrigation system but ammonia $\left(\mathrm{NH}_{3}\right)$ volatilization is the major $\mathrm{N}$ loss pathway from irrigated rice field (De Datta et al., 1991). Ventura and Yoshida (1977) reported reduced $\mathrm{NH}_{3}$ volatilization under AWD than continuous flooded condition. AWD can lower water use for irrigated rice by $35 \%$ (Zhang et al., 2009), increase rice yield by $\sim 10 \%$ relative to permanent flooding (Yang et al., 2009; Zhang et al., 2009). Hence, the effect of deep placement of $\mathrm{N}$ fertilizer on yield and nitrogen use efficiency of boro rice under two different water regimes were examined in this study.

\section{MATERIALS AND METHODS}

Two experiments were conducted under continuous flooded (CF) and AWD conditions with similar N fertilizer treatment at the Soil Science Field Laboratory of Bangladesh Agricultural University, Mymensingh to evaluate the effect of water regimes on the yield and $\mathrm{N}$ use efficiency in boro rice. The soil belongs to Sonatala series under the AEZ-9 (Old Brahmaputra Floodplain). The soils were silt loam in texture. In AWD condition, the soil had $\mathrm{pH}$ 6.07, organic matter content $1.10 \%$, 
total N $0.055 \%$, available P 3.8 ppm, exchangeable $\mathrm{K} 0.24 \mathrm{meq} \%$ and available S $12.56 \mathrm{ppm}$. In continuous flooding condition the soil had $\mathrm{pH} 6.27$, organic matter content $1.95 \%$, total N $0.136 \%$, available P 3.16 ppm, exchangeable K 0.095 meq\% and available $\mathrm{S} 10.5 \mathrm{ppm}$.

There were 7 treatments consisting of different sources of $\mathrm{N}$ and these include- $\mathrm{T}_{1}=$ Control, $\mathrm{T}_{2}=\mathrm{PU} 156 \mathrm{~kg} \mathrm{~N} \mathrm{ha}^{-1}, \mathrm{~T}_{3}=\mathrm{USG} 156 \mathrm{~kg} \mathrm{~N} \mathrm{ha}^{-1}, \mathrm{~T}_{4}=\mathrm{USG}$ $104 \mathrm{~kg} \mathrm{~N} \mathrm{ha}^{-1}, \mathrm{~T}_{5}=$ USG $78 \mathrm{~kg} \mathrm{~N} \mathrm{ha}{ }^{-1}+\mathrm{PM} 3 \mathrm{tha}^{-1}, \mathrm{~T}_{6}=$ USG $78 \mathrm{~kg} \mathrm{~N} \mathrm{ha}^{-1}+$ CD $3 \mathrm{t}$ $\mathrm{ha}^{-1}$ and $\mathrm{T}_{7}=\mathrm{NPK}$ briqutte $102 \mathrm{~kg} \mathrm{ha}^{-1}$. The experiment was laid out in a Randomized Complete Block Design (RCBD) with three replications. Forty day old rice seedlings were transplanted to the plots maintaining a spacing of $20 \mathrm{~cm} \times 20 \mathrm{~cm}$. Fertilizers were applied as per treatment. All the treatments except $\mathrm{T}_{7}$ received $20 \mathrm{~kg} \mathrm{P}$ and 50 $\mathrm{kg} \mathrm{K} \mathrm{ha}{ }^{-1}$ from TSP and MoP, respectively. $\mathrm{T}_{7}$ received NPK briquette fertilizer. Gypsum was applied to all the plots as basal dose as sulphur. PU was applied in three equal splits as top dress at 10 days after transplanting (DAT); 35 DAT (active tillering stage) and at 55 DAT (panicle initiation stage). USG and NPK briquettes were applied at 10 DAT and were placed at $8-10 \mathrm{~cm}$ depth between four hills at alternate rows.

Different intercultural operations such as weeding, pest control etc was done when required. In continuous flooded plots water was always maintained at $6 \mathrm{~cm}$ depth and thus irrigations were applied as and when necessary. Alternate wetting and drying (AWD) condition was maintained through limited water supply. For proper monitoring a PVC pipe was inserted in control plots and irrigation was provided when the water level goes below $15 \mathrm{~cm}$ down from the surface. The first alternating wetting and drying cycle is deployed 10-15 days after transplanting and continued until the commencement of flowering. The wetting/drying cycle consists of flooding the field followed by dry out $15 \mathrm{~cm}$ below the soil surface (as observed in the tubes); the field is then re-flooded to $2 \mathrm{~cm}$ above the soil surface before next drying cycle begins.

Before collecting water sample, irrigation was given to maintain a water depth of about $6 \mathrm{~cm}$ and for this reason time to time irrigation was done. The field was supposed to irrigate after 3-5 days of depletion of water from the field in order to maintain reduced water condition (alternate wetting and drying condition), although, it was not always feasible practically due to frequent rains. Water samples were collected for 5 consecutive days after deep placement of USG and NPK briquettes and each split application of PU. The concentration of $\mathrm{NH}_{4}-\mathrm{N}$ was determined by Phenol-hypochlorite method (Solorzano, 1969).

The crop was harvested at full maturity and the data on grain and straw yields were recorded. The grain yield was expressed at $14 \%$ moisture basis and straw yield was recorded on sundry basis. The grain and straw samples were analyzed for $\mathrm{N}$ content following semi-micro Kjeldahl method (Bremner and Mulvaney, 1982). The $\mathrm{N}$ uptake by grain and straw was determined from $\mathrm{N}$ content and yield data. The $\mathrm{N}$ 
use efficiency ( $\mathrm{kg}$ grain yield increase $\mathrm{kg}^{-1} \mathrm{~N}$ applied) was determined by the following formula: $\mathrm{NUE}=\left(\mathrm{Gy}+\mathrm{N}-\mathrm{Gy}_{\mathrm{ON}}\right) / \mathrm{FN}$, Where $\mathrm{Gy}+\mathrm{N}=$ grain yield in treatment with $\mathrm{N}$ application; $\mathrm{Gy}_{\mathrm{ON}}=$ grain yield in treatment without $\mathrm{N}$ application and $\mathrm{FN}=$ amount of fertilizer $\mathrm{N}$ applied $\left(\mathrm{kg} \mathrm{ha}^{-1}\right)$. The apparent $\mathrm{N}$ recovery was calculated by the following formula: ANR $\left(\mathrm{kg} \mathrm{ha}^{-1}\right)=\left(\mathrm{UN}_{+\mathrm{N}}-\mathrm{UN}_{0 \mathrm{~N}}\right) / \mathrm{FN}$; where, $\mathrm{UN}_{+\mathrm{N}}$ is total $\mathrm{N}$ uptake $\left(\mathrm{kg} \mathrm{ha}^{-1}\right)$ with grain and straw; $\mathrm{UN}_{0 \mathrm{~N}}$ is the $\mathrm{N}$ uptake $\left(\mathrm{kg} \mathrm{ha}^{-1}\right)$ in control; $\mathrm{FN}$ is amount of fertilizer $\mathrm{N}$ applied $\left(\mathrm{kg} \mathrm{ha}^{-1}\right)$. All the data were statistically analyzed by F-test and the mean differences were ranked by DMRT at 5\% level (Gomez and Gomez, 1984).

\section{RESULTS AND DISCUSSION}

\section{$\mathrm{NH}_{4}-\mathrm{N}$ in flood water}

Ammonium concentration in the water sample was significantly influenced by the application of different treatments have been depicted in figure A. Due to application of PU, USG and NPK briquettes, the concentration of $\mathrm{NH}_{4}-\mathrm{N}$ in flood water varied widely. According to figure $1, \mathrm{NH}_{4}{ }^{+}$concentration rocketed just after the application of first split of PU and in the second day, $\mathrm{NH}_{4}{ }^{+}$concentration in both $\mathrm{CF}$ and AWD conditions reached at its peak. On the other hand, $\mathrm{NH}_{4}{ }^{+}$concentration remained stable in all USG and NPK briquettes treated plots $\left(T_{3}, T_{5}, T_{6}\right.$, and $\left.T_{7}\right)$ except $\mathrm{T}_{5}$ in $\mathrm{CF}$ condition and $\mathrm{T}_{7}$ in AWD condition. After fourth day the concentration of ammonium in the all treatments became almost similar. This reveals that the USG and NPK briquettes treated plots $\left(\mathrm{T}_{3}, \mathrm{~T}_{4}, \mathrm{~T}_{5}, \mathrm{~T}_{6}, 7\right)$ had much lower concentration of ammonium in flood water.

Figure B shows the effect of USG, PU and NPK briquette on $\mathrm{NH}_{4}^{+}$ concentration of water sample collected during 10-14 March, 2013. After two days of $\mathrm{N}$ fertilizer application the highest amount of $\mathrm{NH}_{4}{ }^{+}$concentration $(6 \mathrm{ppm}$ in $\mathrm{CF}$ and 8 ppm in AWD) was recorded for the treatment $\mathrm{T}_{2}\left[\mathrm{PU}, 156 \mathrm{~kg} \mathrm{~N} \mathrm{ha}^{-1}\right]$. After second day, the $\mathrm{NH}_{4}{ }^{+}$concentration started to decrease slowly in PU treated plot and at fifth day it was around 1-2 ppm in both CF and AWD condition. The $\mathrm{NH}_{4}^{+}$concentration in $\mathrm{T}_{3}, \mathrm{~T}_{4}, \mathrm{~T}_{5}, \mathrm{~T}_{6}$, and $\mathrm{T}_{7}$ remain around $1 \mathrm{ppm}$ for the whole time.

Figure $\mathrm{C}$ shows the effect of PU, USG and NPK briquettes on $\mathrm{NH}_{4}{ }^{+}$ concentrations in water samples collected during 1-5 April, 2013. At the second day of $\mathrm{N}$ fertilizer application, the highest amount of $\mathrm{NH}_{4}{ }^{+}$concentrations was produced for the treatment $\mathrm{T}_{2}\left(\mathrm{PU}, 156 \mathrm{~kg} \mathrm{~N}\right.$ ha ${ }^{-1}$ ). After that, $\mathrm{NH}_{4}{ }^{+}$concentration decreased slowly and at fifth day, the concentration in all treatments became almost similar. The treatment $\mathrm{T}_{2}$ gave higher $\mathrm{NH}_{4}{ }^{+}$concentrations compared to the plots treated with USG $\left(\mathrm{T}_{3}, \mathrm{~T}_{4}, \mathrm{~T}_{5}\right.$, and $\left.\mathrm{T}_{6}\right)$ and NPK briquettes $\left(\mathrm{T}_{7}\right)$.

The results on ammonium concentration of boro rice field water demonstrate that the PU treated plots $\left(\mathrm{T}_{2}\right)$ had much higher concentration of ammonium in water compared to the plots treated with USG $\left(\mathrm{T}_{3}, \mathrm{~T}_{4}, \mathrm{~T}_{5}\right.$, and $\left.\mathrm{T}_{6}\right)$ and NPK briquette $\left(\mathrm{T}_{7}\right)$ as shown in figure 1 . The treatment $\mathrm{T}_{2}\left(\mathrm{PU}, 156 \mathrm{~kg} \mathrm{~N} \mathrm{ha}^{-1}\right.$ ) showed the maximum $\mathrm{NH}_{4}-\mathrm{N}$ 
concentration followed by treatment $\mathrm{T}_{4}$ (USG, $104 \mathrm{~kg} \mathrm{~N} \mathrm{ha}^{-1}$ ). Within five days, the $\mathrm{NH}_{4-}$ $\mathrm{N}$ concentration in all the treatments became almost similar. The USG treated plots $\left(\mathrm{T}_{3}, \mathrm{~T}_{4}\right.$, $\mathrm{T}_{5}$ and $\left.\mathrm{T}_{6}\right)$ and NPK briquette treated plots $\left(\mathrm{T}_{7}\right)$ had much lower concentration of ammonium in flood water indicating that deep placement of urea fertilizer can reduce $\mathrm{N}$ loss by ammonia volatilization. Deep placement of $\mathrm{N}$ reduces ammonium $\mathrm{N}$ in floodwater. This not only improves $\mathrm{N}$ use efficiency in rice but also minimizes $\mathrm{N}$ loss resulting from ammonia volatilization and denitrification (Savent and Stangel, 1990; Mohanty et al., 1999). This finding is also accorded with Xiang et al. (2013). There were sharp decline in the amount of $\mathrm{NH}_{4}-\mathrm{N} ; 2$ to 3 days after broadcasting of PU may be attributed to volatilization loss, diffusion of $\mathrm{NH}_{4}-\mathrm{N}$ into soil, and / or nitrification losses.

\section{Grain yield}

The grain yield boro rice was responded significantly due to water management and the application of PU, USG and NPK briquette (Figure 2). In AWD condition the grain yield ranged from 3033 to $6714 \mathrm{~kg} \mathrm{ha}^{-1}$ and in continuous flooded condition it was varied from 3261 to $6425 \mathrm{~kg} \mathrm{ha}^{-1}$. In both condition, the highest grain yield was recorded in $\mathrm{T}_{5}$ (USG $78 \mathrm{~kg} \mathrm{~N} \mathrm{ha}^{-1}+\mathrm{PM} 3 \mathrm{t} \mathrm{ha}^{-1}$ ) and the lowest in $\mathrm{T}_{1}$ (control). USG with poultry manure followed by USG performed better in increasing grain yield of rice compared to PU and NPK briquette alone. On the other hand, higher grain yield is found with AWD condition compared to CF condition in every treatment except $\mathrm{T}_{1}$ and $\mathrm{T}_{7}$.

\section{Straw yield}

Straw yield of boro rice also responded significantly to different treatments (Figure 3). In AWD condition, the highest straw yield $\left(6516 \mathrm{~kg} \mathrm{ha}^{-1}\right)$ was found in $\mathrm{T}_{5}$ (USG, $78 \mathrm{~kg} \mathrm{~N} \mathrm{ha}^{-1}+\mathrm{PM} 3 \mathrm{t} \mathrm{ha}^{-1}$ ) and the lowest value (3214 $\left.\mathrm{kg} \mathrm{ha}^{-1}\right)$ in $\mathrm{T}_{1}$ (control). The straw yield produced by the treatment $T_{3}$ was identical to $T_{5}$. In case of continuous flooded condition, the maximum straw yield $\left(7428 \mathrm{~kg} \mathrm{ha}^{-1}\right)$ was obtained from the treatment $\mathrm{T}_{5}$ which was identical with that of treatment $\mathrm{T}_{2}(\mathrm{PU}, 156 \mathrm{~kg} \mathrm{~N}$ ha ${ }^{1}$ ), $\mathrm{T}_{3}$ and $\mathrm{T}_{4}$ (USG, $104 \mathrm{~kg} \mathrm{~N} \mathrm{ha}^{-1}$ ). Every treatment except $\mathrm{T}_{3}$ under $\mathrm{CF}$ condition gave better straw yield compared to AWD condition.

\section{Nitrogen uptake}

It was revealed from the figure 4 that the total $\mathrm{N}$ uptake by boro rice was influenced significantly by the application of PU, USG and NPK briquettes under CF and AWD condition. In CF condition, the highest total $\mathrm{N}$ uptake was observed in treatment $\mathrm{T}_{6}\left(78 \mathrm{k} \mathrm{g} \mathrm{N} \mathrm{ha}^{-1}\right.$ from USG $\left.+\mathrm{CD} 3 \mathrm{t} \mathrm{ha}^{-1}\right)$ was statistically identical to $\mathrm{T}_{7}$ (102 $\mathrm{kg} \mathrm{N} \mathrm{ha}^{-1}$ as NPK briquette), $\mathrm{T}_{5}\left(78 \mathrm{~kg} \mathrm{~N} \mathrm{ha}^{-1}\right.$ from USG + PM $3 \mathrm{t} \mathrm{ha}^{-1}$ ) and $\mathrm{T}_{3}$ (156 kg N as USG). In AWD condition, the maximum total $\mathrm{N}$ uptake was recorded in $\mathrm{T}_{5}$ [USG, $78 \mathrm{~kg} \mathrm{~N} \mathrm{ha}^{-1}+\mathrm{PM} 3 \mathrm{t} \mathrm{ha}^{-1}$ ] followed by $\mathrm{T}_{3}$ [USG, $156 \mathrm{~kg} \mathrm{~N} \mathrm{ha}^{-1}$ ]. On the other hand, treatments $\mathrm{T}_{2}$ (PU, $156 \mathrm{~kg} \mathrm{~N} \mathrm{ha}^{-1}$ ), $\mathrm{T}_{4}$ (USG, $104 \mathrm{~kg} \mathrm{~N} \mathrm{ha}^{-1}$ ) and $\mathrm{T}_{6}(\mathrm{USG}$, $78 \mathrm{~kg} \mathrm{~N} \mathrm{ha}+\mathrm{CD} 3 \mathrm{t} \mathrm{ha}^{-1}$ ) gave statistically similar total $\mathrm{N}$ uptake. The results 
revealed that that the total $\mathrm{N}$ uptake by rice grain and straw was increased significantly with the deep placement of USG combined with organic manure in all the treatments but $\mathrm{T}_{7}$ and $\mathrm{T}_{1}$ gave significantly higher $\mathrm{N}$ uptake in AWD condition compared to $\mathrm{CF}$.

\section{Apparent $\mathrm{N}$ recovery}

The apparent $\mathrm{N}$ recovery (ANR) indicates the absorption efficiency of applied $\mathrm{N}$. According to figure 5 mean apparent recovery of $\mathrm{N}$ by rice ranged from 36.26 to $55.79 \%$ in different treatments under AWD condition and 26.97 to $52.77 \%$ in CF. The maximum value of ANR was obtained with the application of USG in treatment

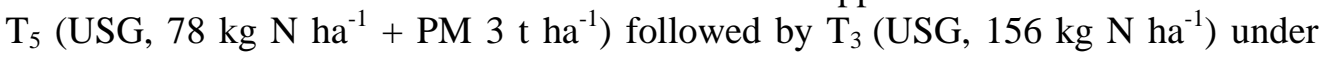
AWD condition whereas (78 $\mathrm{kg} \mathrm{N}$ as USG $+\mathrm{CD} 3 \mathrm{t}$ ) followed by $\mathrm{T}_{7}(102 \mathrm{~kg} \mathrm{~N}$ as NPK briquette) gave the maximum ANR value under CF condition. The data clearly indicate that the deep placement of USG enhanced the recovery of applied $\mathrm{N}$ compared to broadcast application of NPK fertilizers.

\section{Nitrogen use efficiency}

Nitrogen use efficiency (NUE) represents the response of rice plant in terms of grain yield to $\mathrm{N}$ fertilizer. NUE responded significantly due to different treatment combinations in CF and AWD condition. The range of NUE varied from 12.86 to 28 $\mathrm{kg}$ grain increase per $\mathrm{kg} \mathrm{N}$ applied (Figure 6) in $\mathrm{CF}$ condition. The maximum value (28 kg grain increase per kg N applied) was obtained in $\mathrm{T}_{7}\left(102 \mathrm{~kg} \mathrm{~N} \mathrm{ha}^{-1}\right.$ from NPK briquette) followed by $\mathrm{T}_{5}\left(25.11 \mathrm{~kg}\right.$ grain increase per $\mathrm{kg} \mathrm{N}$ applied), $\mathrm{T}_{6}(24.06 \mathrm{~kg}$ grain increase per $\mathrm{kg} \mathrm{N}$ applied), $\mathrm{T}_{4}(18.29 \mathrm{~kg}$ grain increase per $\mathrm{kg} \mathrm{N}$ applied) and the lowest value in $\mathrm{T}_{3}\left(156 \mathrm{~kg} \mathrm{~N}^{-1}\right.$ from USG). In AWD condition, the maximum value of NUE (29.21 kg grain increase per $\mathrm{kg} \mathrm{N}$ applied) was obtained in $\mathrm{T}_{5}$ (USG, $\left.78 \mathrm{~kg} \mathrm{~N} \mathrm{ha}^{-1}+\mathrm{PM} 3 \mathrm{t} \mathrm{ha}^{-1}\right)$ followed by $\mathrm{T}_{4}(25.57 \mathrm{~kg}$ grain increase per $\mathrm{kg} \mathrm{N}$ applied), $\mathrm{T}_{6}\left(25.57 \mathrm{~kg}\right.$ grain increase per $\mathrm{kg} \mathrm{N}$ applied), $\mathrm{T}_{3}(23.54 \mathrm{~kg}$ grain increase per $\mathrm{kg} \mathrm{N}$ applied), $\mathrm{T}_{7}(20.82 \mathrm{~kg}$ grain increase per $\mathrm{kg} \mathrm{N}$ applied) and the minimum value was found in $\mathrm{T}_{2}$ (18.62 $\mathrm{kg}$ grain increase per $\mathrm{kg} \mathrm{N}$ applied). These results indicates that application of NPK briquettes and USG in combination with organic manure in rice field decreases the losses of $\mathrm{N}$ or the rate of $\mathrm{N}$, leading to efficient uptake and utilization of applied $\mathrm{N}$ under AWD condition compared to CF condition.

\section{CONCLUSION}

The overall results indicate that the treatment comprising $T_{2}, T_{3}, T_{4}, T_{5}$ produced the higher grain yield under AWD condition. Similarly, the highest $\mathrm{N}$ recovery and $\mathrm{N}$ use efficiency were also found in the same treatments as compared to CF condition. This reveals that the deep placement of USG fertilizer under AWD

condition enhanced the $\mathrm{N}$ use efficiency. On the other hand, $\mathrm{T}_{6}, \mathrm{~T}_{7}$ gave the maximum grain yield, $\mathrm{N}$ recovery and $\mathrm{N}$ use efficiency under $\mathrm{CF}$ condition compared to AWD condition. 


\section{ACKNOWLEDGEMENT}

This research was partially supported by the Ministry of Science and Technology, Government of the People's Republic of Bangladesh.

\section{REFERENCES}

BBS, Bangladesh Bureau of Statistics. 2011. Statistical Year Book of Bangladesh. Statistical Division, Ministry of Planning, Govt. People's Republic Bangladesh

BBS, Bangladesh Bureau of Statistics. 2012. Monthly Statistical Bulletin of Bangladesh. Statistics Div. Ministry of Planning, Govt. People's Republic Bangladesh

Belder, P., Bouman, B. A. M., Cabangon, R., Guoan, L., Quilang, E. J. P., Yuanhua, L., Spiertz, J. H. J. and Tuong, T. P. 2004. Effect of water-saving irrigation on rice yield and water use in typical lowland conditions in Asia. Agricultural Water Management, 65: $193-210$

De Datta, S. K., Samson, M. I., Obcemea, W. N., Real, J. G. and Buresh, R. J. 1991. Direct measurement of ammonia and denitrification fluxes from urea applied to rice. Soil Science Society of American Journal, 55 :543-548

Gomez, K. A. and Gomez, A. A. 1984. Statistical Procedures for Agricultural Research. $2^{\text {nd }}$ Edition, John Wiley and Sons, New York. pp. 97-111

Liu, S., Qin, Y., Zou, J. and Liu, Q. 2010. Effects of water regime during rice-growing season on annual direct $\mathrm{N}_{2} \mathrm{O}$ emission in a paddy rice-winter wheat rotation system in southeast China. Science of the Total Environment, 408: 906-913

Nicolaisen, M. H., Risgaard-Petersen, N., Revsbech, N. P., Reichardt, W. and Ramsing, N. B. 2004. Nitrification-denitrification dynamics and community structure of $\mathrm{NH}_{3}$-oxidizing bacteria in a high yield irrigated Philippine rice field. FEMS Microbiology Ecology. 49: 359-369

Mikkelsen, D. S., De Datta, S. K. and Obcemea, W. N. 1978. Ammonia volatilization losses from flooded rice soils. Soil Science Society of American Journal, 42:725-730

Mohanty, S. K., Singh, U., Balasubramanian, V., Jha, K. P. 1999. Nitrogen deep placement technologies for productivity, profitability and environmental quality of rainfed low land rice systems. Nutrient Cycling in Agro-ecosystems, 53: 43-57

Savant, N. K. and Stangel, P. J. 1990. Deep placement of urea super granule in transplanted rice: principles and practices. Nutrient Cycling in Agro-ecosystems, 25: 1-83

Solorzano, L. 1969. Determination of Ammonia in Natural Waters by the Phenolhypochloride Method. Limnology and Oceanography. 14: 799-801

Ventura, W. B. and Yoshida, T. 1977. Ammonia volatilization from a flooded tropical soil. Plant and Soil. 46: 521-531

Xiang, J., Haden, V. R., Bouman, A. M. and Zhu, D. 2013. Effect of deep placement of nitrogen fertilizer on growth, yield and nitrogen uptake of aerobic rice. Australian Journal of Crop Science, 7(6): 870-877 
Yang, J. C., D. Huang., H, Duan., Tan, G. and Zhang, J. 2009. Alternate wetting and moderate drying increase grain yield and reduces cadmium accumulation in rice grains. Journal of the Science of Food and Agriculture, 89: 1728-1736

Zhang, H., Xue, Y., Wang, Z. Yang, J. and Zhang, J. 2009. Alternate wetting and moderate soil drying improves root and shoot growth in rice. Crop Science, 49: 2246-2260

Zhu, Z. L., Wen, Q. X. and Freney, J. R. 1997. Nitrogen in Soils of China. Kluwer Academic Publishers, Dordrecht 

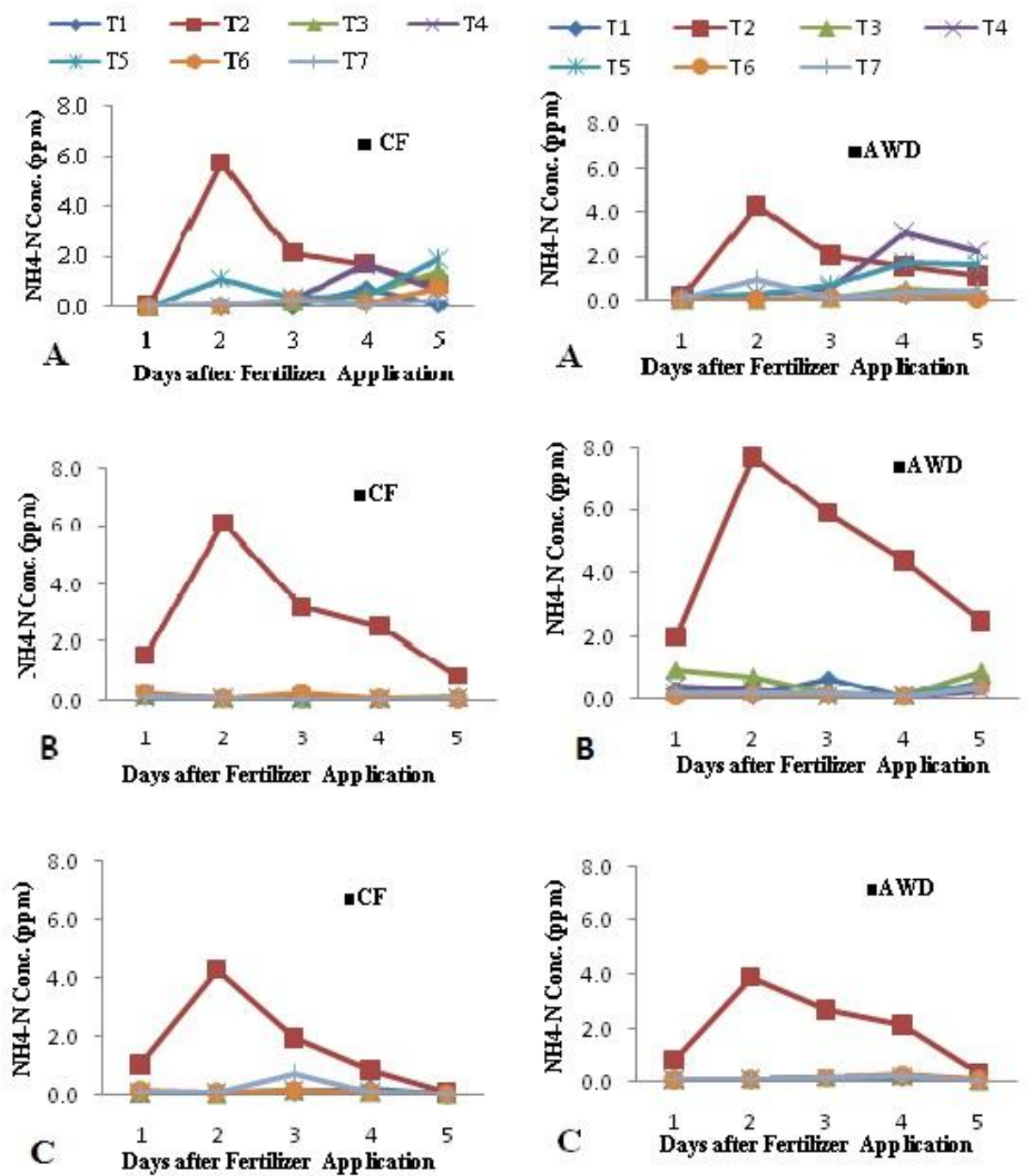

Figure 1. Ammonium concentration in floodwater after deep placement of $\mathrm{N}$ fertilizers under Continuous Flooding (CF) and Alternate Wetting and Drying (AWD) Condition. [A: First Sampling; B: Second Sampling; C: Third Sampling] 


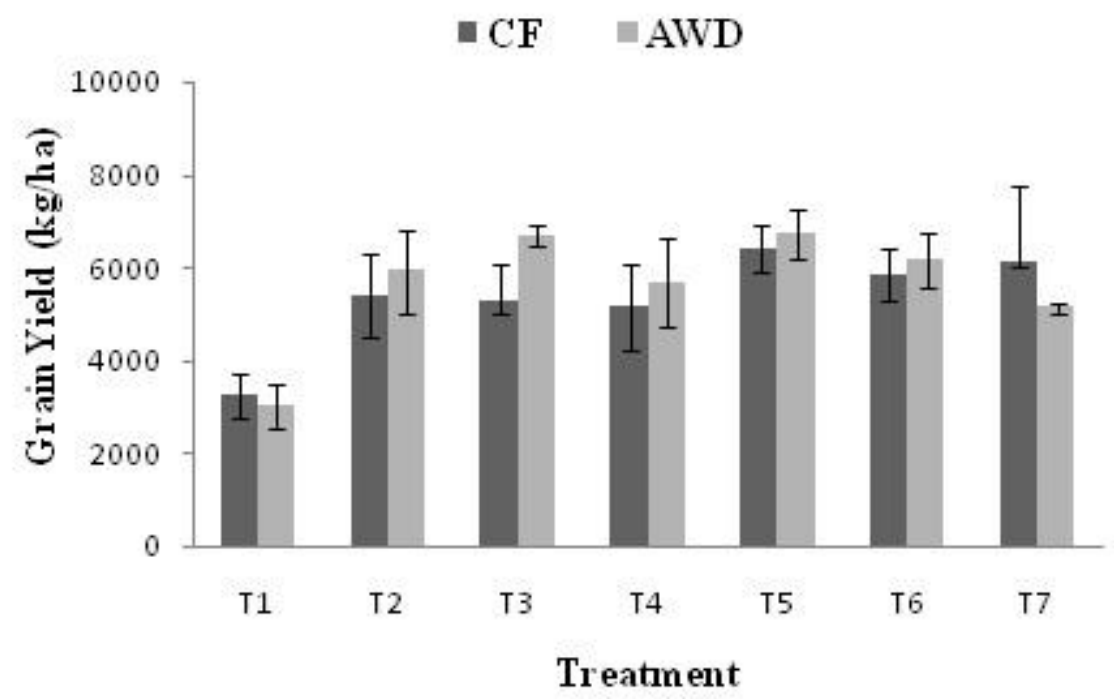

Figure 2. Grain Yield as influenced by the deep placement of $\mathrm{N}$ fertilizers under $\mathrm{CF}$ and AWD condition [CF: Continuous Flooding; AWD: Alternate Wetting and Drying]

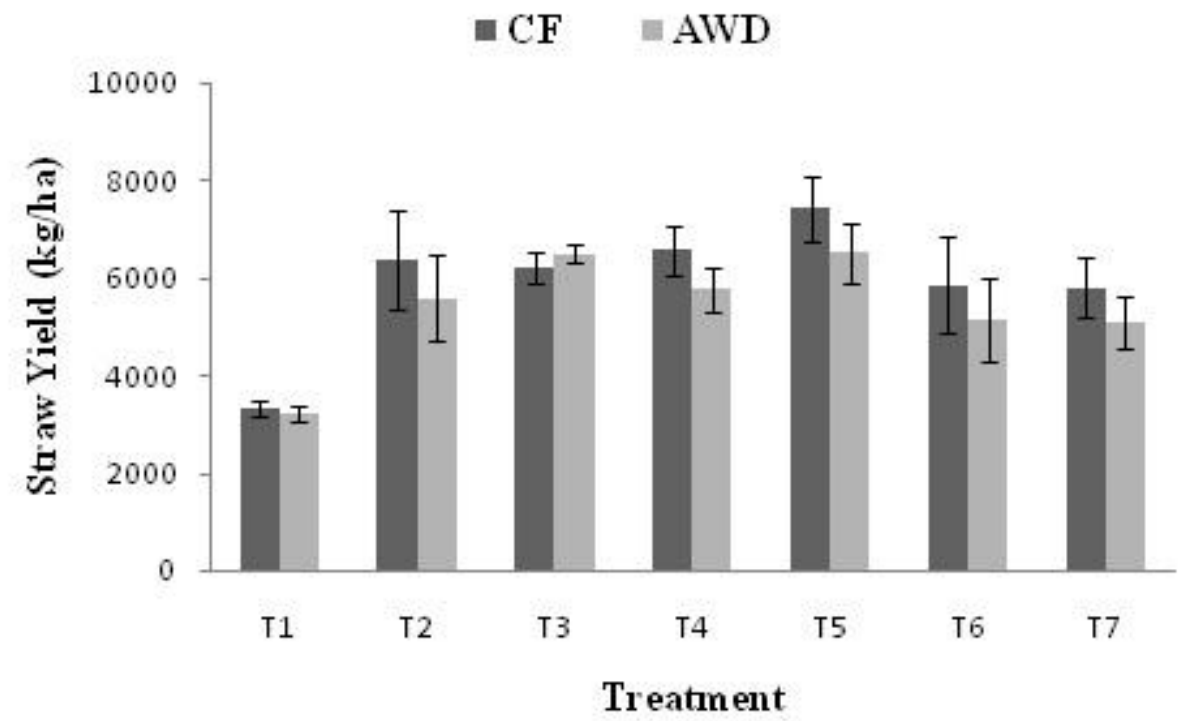

Figure 3. Straw Yield as influenced by the deep placement of $\mathrm{N}$ fertilizers under $\mathrm{CF}$ and AWD condition [CF: Continuous Flooding; AWD: Alternate Wetting and Drying] 


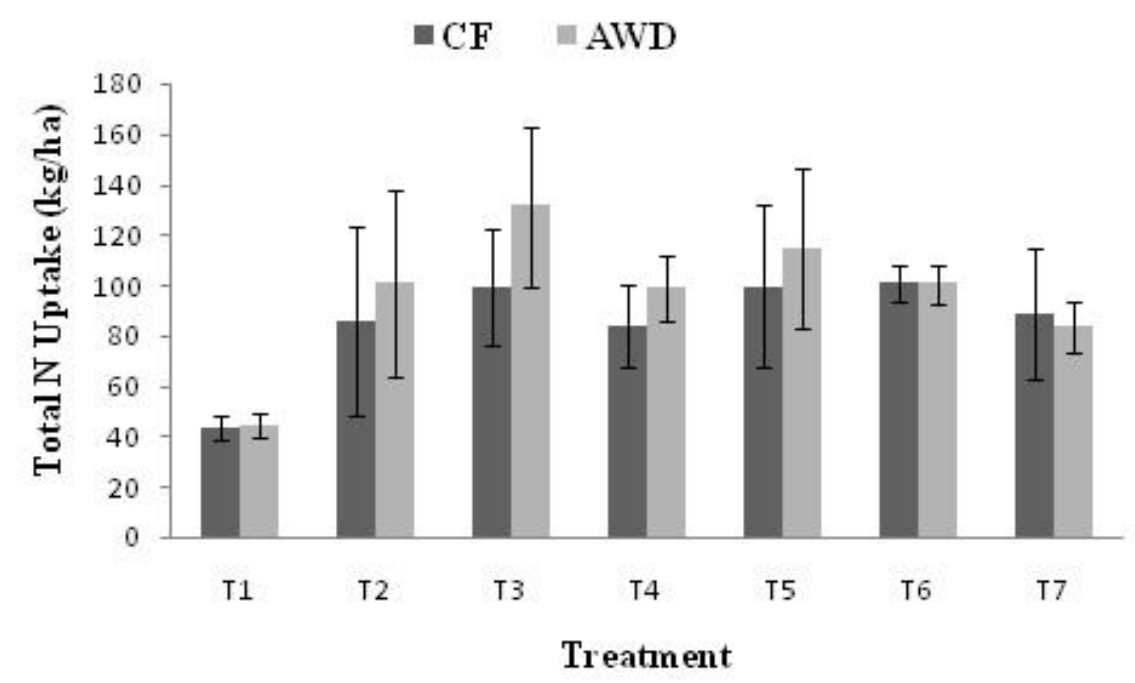

Figure 4. Total N Uptake as influenced by the deep placement of $\mathrm{N}$ fertilizers under $\mathrm{CF}$ and AWD condition [CF: Continuous Flooding; AWD: Alternate Wetting and Drying]

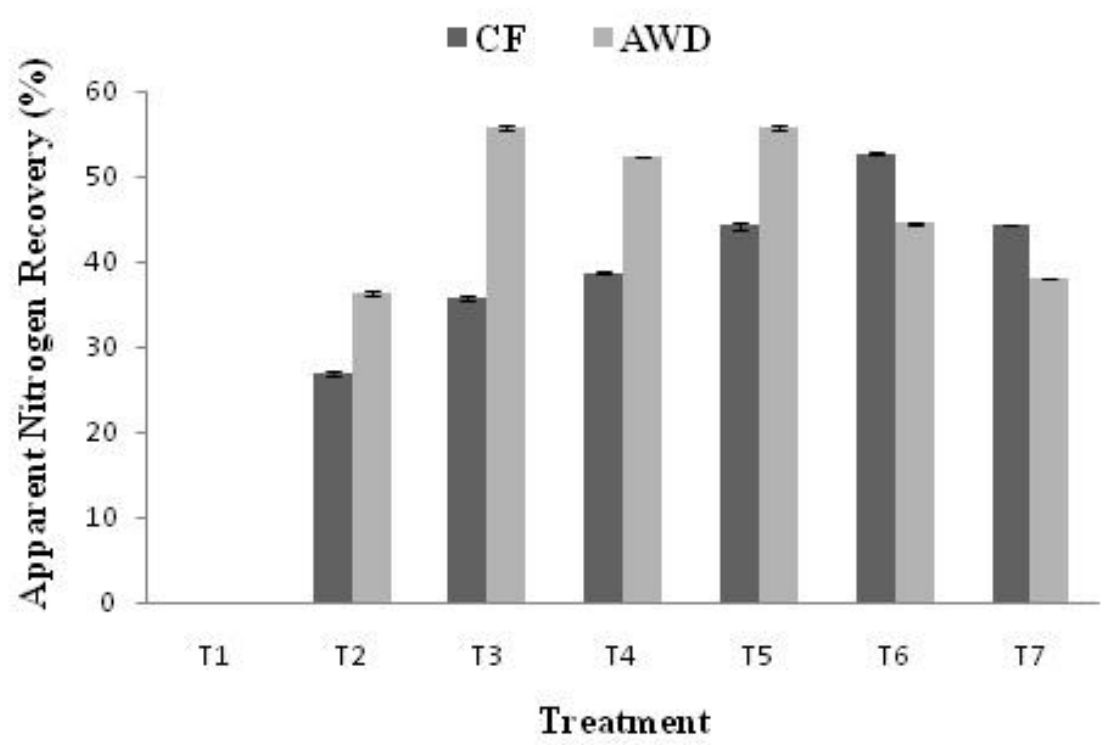

Figure 5. Apparent Nitrogen Recovery (ANR) as influenced by the deep placement of N fertilizers under CF and AWD condition [CF: Continuous Flooding; AWD: Alternate Wetting and Drying] 


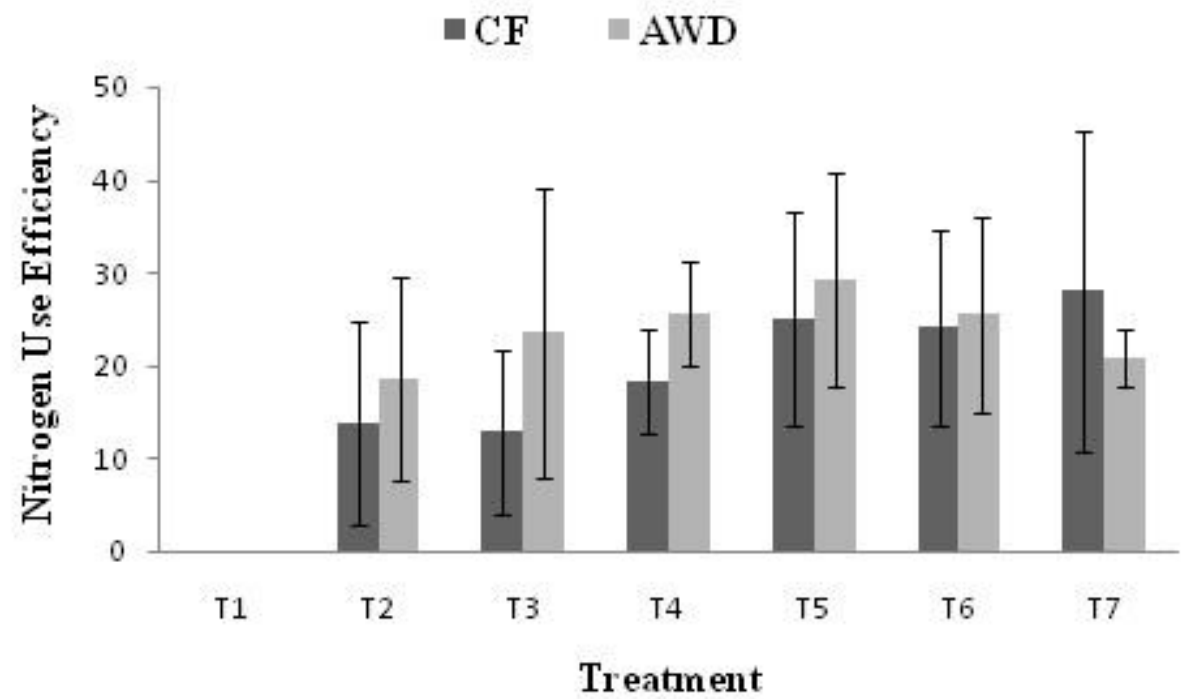

Figure 6. Nitrogen Use Efficiency as influenced by the deep placement of $\mathrm{N}$ fertilizers under CF and AWD condition [CF: Continuous Flooding; AWD: Alternate Wetting and Drying] 